F. Reprod. Fert. (1974) 38, 201-204

\title{
NORMAL DURATION OF THE OESTROUS CYCLE IN EWES WITH CONGENITAL ABSENCE OF ONE UTERINE HORN
}

\author{
J. D. O'SHEA, C. S. LEE AND I. A. CUMMING \\ Department of Veterinary Preclinical Sciences, University of Melbourne, \\ Parkville, Victoria 3052, and \\ Department of Agriculture, S.S. Cameron Laboratory, State Research Farm, \\ Werribee, Victoria 3030, Australia
}

(Received 6th November 1973)

\begin{abstract}
Summary. Normal oestrous cycles occurred in five ewes in which the left uterine horn was congenitally absent. In all of these ewes, the blood vessels supplying the left ovary were essentially normal, and large uterine veins drained into the left utero-ovarian vein. Normal cyclical activity in these circumstances is consistent with a mechanism of luteolysis involving local countercurrent transfer of prostaglandin $\mathrm{F}_{2 \alpha}$ in the uterine and ovarian vessels.
\end{abstract}

The effect of unilateral hysterectomy in ewes in prolonging luteal life span in the ipsilateral ovary has been amply demonstrated (Inskeep \& Butcher, 1966; Moor \& Rowson, 1966). Hence, it might be predicted that congenital absence of one uterine horn would have a similar effect, and McCracken \& Caldwell (1969) reported a case in which this apparently occurred. Subsequently, Hunter (1970) described two ewes in which the left uterine horn and oviduct were congenitally absent, but in which oestrous cyclical activity was normal. On this evidence, Hunter (1970) questioned the view that there is a significant local relationship between a uterine horn and its adjacent ovary.

Recent experimental evidence (Barrett, Blockey, Brown, Cumming, Goding, Mole \& Obst, 1971; Restall, Hearnshaw, Gleeson \& Thorburn, 1973; Ginther, Del Campo \& Rawlings, 1973) has shown that successful luteolysis depends on the close relationship of veins draining the uterus and arteries supplying the ovary, rather than on the ipsilateral presence of a uterine horn in itself. An explanation for the findings of Hunter (1970) which does not conflict with the recently proposed countercurrent transfer mechanism of local luteolysis (Goding, Cumming, Chamley, Brown, Cain, Cerini, Cerini, Findlay, O'Shea \& Pemberton, 1971/72; McCracken, Carlson, Glew, Goding, Baird, Green \& Samuelsson, 1972) could, therefore, be found if the artery supplying the ovary on the side of the missing uterine horn was in close contact with veins draining the uterus.

This paper reports data on reproductive function and anatomy in five 
ewes in which the left uterine horn was congenitally absent, but in which the duration of the oestrous cycle was normal.

Details of the five ewes are shown in Table 1. Ewes I, II and III were all born on the same property, while Ewes IV and V were obtained from two separate properties. In all ewes, absence of the left uterine horn was discovered by chance when laparotomies were performed for a variety of reasons before 1973.

Cycle lengths in these five ewes were studied for various periods between January and May 1973. During these periods the ewes were grazed in 1- to 2-hectare paddocks, in groups of twenty to thirty, with normal ewes and with vasectomized rams fitted with harnesses and marking crayons (Radford, Watson \& Wood, 1960). Observation of the ewes was carried out daily, and the crayon colours were changed every 14 days.

All ewes were slaughtered in July or August, 1973. The genital tracts were removed and the ovarian arteries and veins on one or both sides were cannulated, flushed with normal saline, and injected with latex. The genital tracts were fixed in $10 \%$ formalin, dehydrated, and cleared in a 1:3 mixture of alcohol and methyl salicylate.

Table 1. Year of birth, breed and duration of oestrous cycles in five years with congenital absence of the left uterine horn

\begin{tabular}{c|c|c|c}
\hline $\begin{array}{c}\text { Sheep } \\
\text { no. }\end{array}$ & $\begin{array}{c}\text { rear of } \\
\text { birth }\end{array}$ & Breed & \multicolumn{1}{|c}{$\begin{array}{c}\text { Cycle lengths in } 1973 \\
\text { (days) }\end{array}$} \\
\cline { 2 - 3 } I & 1969 & Merino & $15,22,18,37,21$ \\
II & 1969 & Merino & $18,34,16,16$ \\
III & 1968 & Merino & $20,33,19,14$ \\
IV & 1968 & Merino & $17,15,18,20,15,16$ \\
V & 1966 & Corriedale & $20,18,21,20$ \\
\hline
\end{tabular}

Ewe V gave birth to single lambs in 1969 and 1971, and to twins in 1970. Eggs which were apparently developing normally were recovered on flushing the right oviduct in Ewes I and III in fertilization rate studies in 1971.

On examination of the ovaries at laparotomy in 1971, single corpora lutea were observed on the right ovary in Ewes I, II and III. Limited records of the lengths of oestrous cycles for Ewes I, II and IV before 1973 showed a range of 14 to 18 days. The duration of all cycles recorded during 1973 is shown in Table 1.

In all ewes, there was complete absence of the left uterine horn. The right horn and oviduct appeared normal apart from some distortion of outline, which was most marked in Ewe II (Pl. 1, Fig. 1). The right ovary tended to lie closer than normal to the body of the uterus. No recent GL were present in the right ovary of any of the ewes.

The left ovary appeared normal in all ewes, and contained two regressing CL in Ewe I, and a single large CL in Ewes II and III. The oviduct on the left side was present to a variable degree. In all ewes, there was some development of the infundibulum, and, with the exception of Ewe V, there was also a blind ampullary component ranging from $1.5 \mathrm{~cm}$ in length in Ewe IV to 

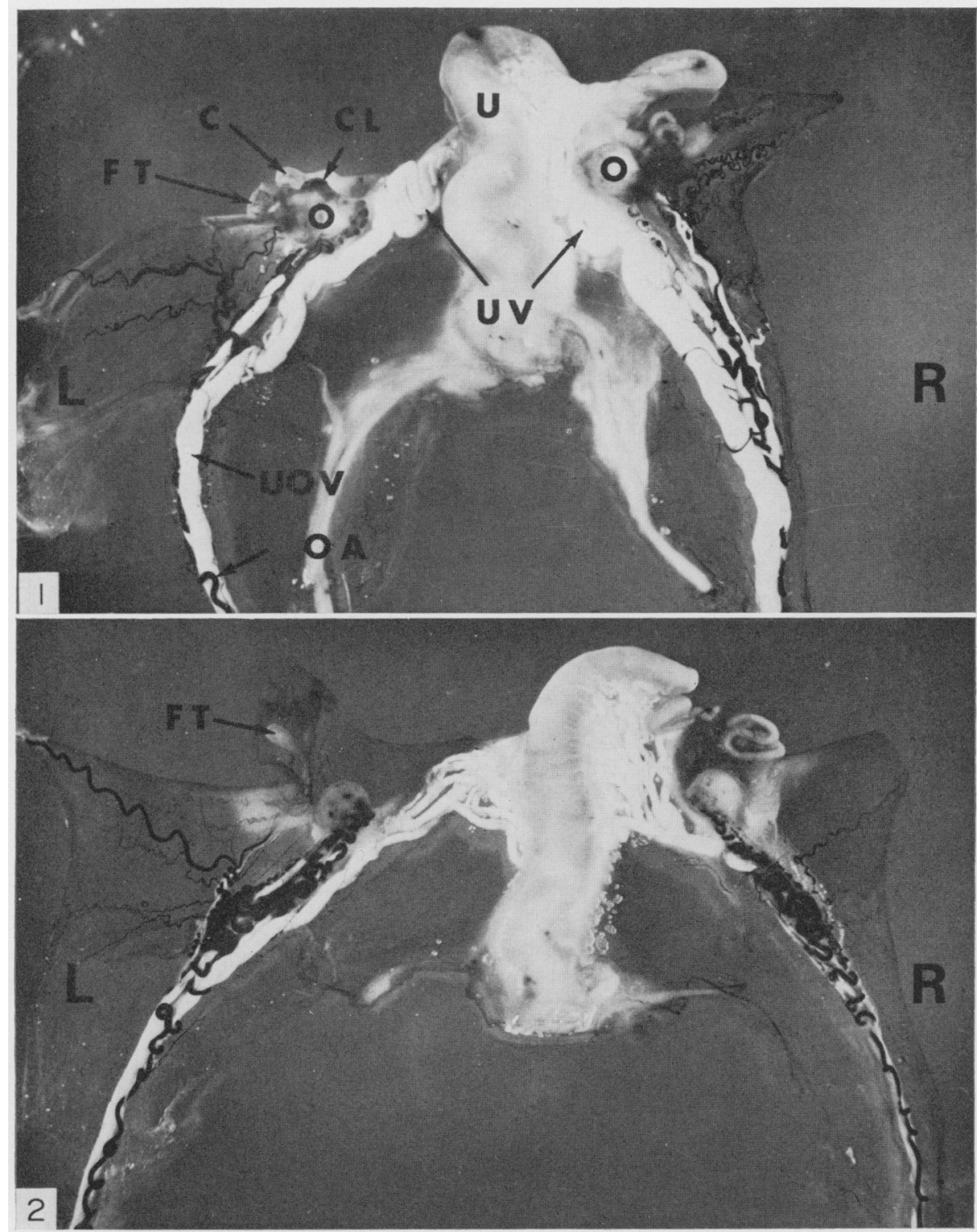

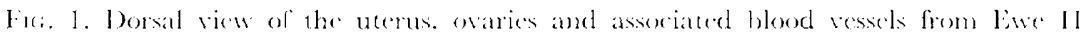

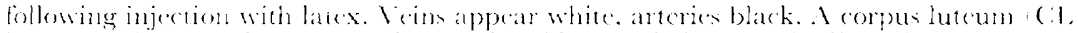
is present in the left ovare and the left oviduet colds in a crotic distension (Ci. latege

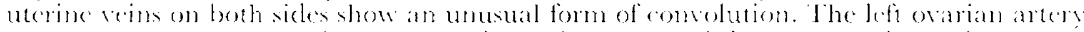
ruas a torturus course along the surface of the batge left utero-orarian reine l"l =

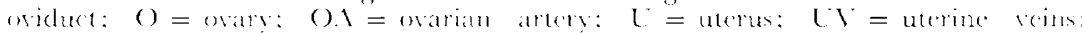
$\mathrm{L}())^{\circ}=$ ut(er)-ovatian rein.

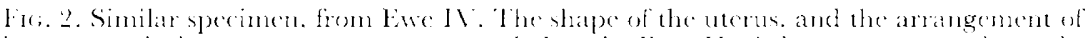

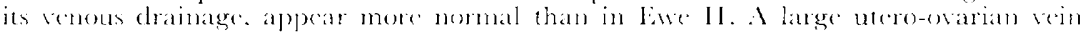

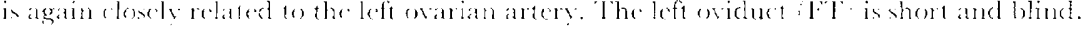


$8.5 \mathrm{~cm}$ in Ewe II. In Ewes I, II and III, there was cystic distension of the terminal portion of the ampulla, most extensive in Ewe II in which a thinwalled, watery fluid-filled region 1.5 by $0.6 \mathrm{~cm}$ was present.

The uterine and ovarian blood vessels and their branches on the right side appeared normal except that, in Ewes II, III and V, the main vein draining the uterus showed an unusual form of convolution (Pl. 1, Fig. 1). The equivalent vessels on the left closely mirrored those on the right in all ewes, and there were many anastomotic connections between the uterine veins of the left and right sides. In spite of the absence of the left horn, a large uterine venous branch joined the left ovarian veins to form a utero-ovarian vein of approximately normal proportions (Pl. 1, Figs 1 and 2). The utero-ovarian vein lay in its normal close relationship with the tortuous ovarian artery. The left ovarian artery or arteries were closely wound around and between the plexiform ovarian veins (Pl. 1, Fig. 2).

Thus, in all of these five ewes the relationship between the arteries supplying the ovary and veins draining the uterus was almost normal. In these circumstances, normal luteolysis on the left side would be predicted on the basis of the experiments of Ginther et al. (1973), and would be consistent with the hypothesis that luteolysis is normally brought about by the countercurrent transfer of prostaglandin $F_{2 \alpha}$ from uterine venous to ovarian arterial blood (Goding et al., 1971/72; McCracken et al., 1972). The normal cyclical activity recorded in these ewes, in which ovulation clearly took place on the left side on some occasions, bears out this prediction.

Although single cycles in Ewes I, II and III were longer than normal, in each instance the long cycle was almost precisely double the mean length of the remaining cycles in the same ewe. This strongly suggests that 'silent ovulation' or undetected oestrus may have occurred in these ewes. Similar long cycles were seen with approximately the same frequency in normal ewes studied at the same time.

The present data provide an explanation for the normal cycle lengths recorded by Hunter (1970) in unicornual ewes, if it is assumed that the vascular relationships in Hunter's ewes were similar to those described here. The reason for the absence of cyclical activity reported by McCracken \& Caldwell (1969) remains uncertain. Hunter (1970) suggested the possibility of 'silent ovulations': an alternative possibility would be that vascular relationships were not normal on the side of the missing horn.

In the ewes described here, the left oviduct was at least partly represented in all animals, offering a possible alternative source of luteolysin. However, in the two ewes reported by Hunter (1970), in which there was complete absence of the left oviduct, this could not have applied.

It is of interest that in the total of eight congenitally unicornual ewes that have now been described, the left horn was missing in every instance. This seems an unlikely coincidence, and suggests the possibility of some common, although at present unknown, aetiology.

We wish to acknowledge that Dr M. A. de B. Blockey drew our attention to the occurrence of a number of ewes with one uterine horn absent, and to 
thank Mr R. W. Baxter, Mr R. Parr and Mr P. Langdon for technical assistance.

\section{REFERENCES}

Barrett, S., Blockey, M. A. de B., Brown, J. M., Gumming, I. A., Goding, J. R., Mole, B. J. \& Onst, J. M. (1971) Initiation of the oestrous cycle in the ewe by infusion of $\mathrm{PGF}_{2 \alpha}$ to the autotransplanted ovary. F. Reprod. Fert. 24, 136.

Ginther, O. J., Del Campo, G. H. \& Rawlings, G. A. (1973) Vascular anatomy of the uterus and ovaries and the unilateral luteolytic effect of the uterus: a local venoarterial pathway between uterus and ovaries in sheep. Am. 7. vet. Res. 34, 723.

Goding, J. R., Gumming, I. A., Ghamley, W. A., Brown, J. M., Cain, M. D., Cerini, J. C., Cerini, M. E. D., Findlay, J. K., O'SheA, J. D. \& Pemberton, D. H. (1971/72) Prostaglandin F $2 \alpha$ 'the' luteolysin in the mammal? Gynecol. Invest. 2, 73.

Hunter, G. L. (1970) Life-span of corpora lutea in ewes with one congenitally absent uterine horn. F. Reprod. Fert. 23, 131.

InSkeEP, E. K. \& Butcher, R. L. (1966) Local component of utero-ovarian relationships in the ewe. 7. Anim. Sci. 25, 1164.

McGracken, J. A. \& Caldwell, B. V. (1969) Corpus luteum maintenance in a ewe with one congenitally absent uterine horn. F. Reprod. Fert. 20, 139.

McGracken, J. A., Garlson, J. C., Glew, M. E., Goding, J. R., Baird, D. T., Green, K. \& Samuelsson, B. (1972) Prostaglandin $\mathbf{F}_{2 \alpha}$ identified as a luteolytic hormone in sheep. Nature, New Biology, 238, 129.

Moor, R. M. \& Rowson, L. E. A. (1966) Local uterine mechanisms affecting luteal function in the sheep. 7. Reprod. Fert. 11, 307.

Radford, H. M., Watson, R. H. \& Wood, G. F. (1960) A crayon and associated harness for the detection of mating under field conditions. Aust. vet. 7. 36, 57.

Restall, B. J., Hearnshaw, H. R., Gleeson, A. R. \& Thorburn, G. D. (1973) Observations on the luteolytic action of prostaglandin $\mathrm{F}_{2 \alpha}$ in the ewe. . Reprod. Fert. 32, 325. 